\title{
Oleanolic acid derivative SZC014 inhibit cell proliferation and induce apoptosis of human breast cancer cells in a ROS-dependent way
}

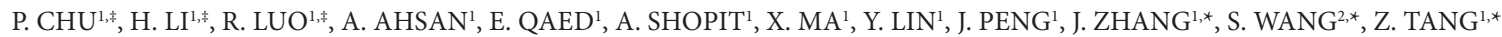 \\ ${ }^{1}$ Department of Pharmacology, Dalian Medical University, Dalian, Liaoning 116044; ${ }^{2}$ College of Pharmaceutical Science and Technology, Dalian \\ University of Technology, Dalian, Liaoning 116024, P.R. China
}

*Correspondence: zhangjb@dmu.edu.cn, shishengw@163.com,tangzeyao@aliyun.com

${ }^{*}$ Contributed equally to this work.

Received September 16, 2016 / Accepted February 1, 2017

\begin{abstract}
Oleanolic acid (OA) and its derivatives are a novel emerging class of compounds. Although OA exhibits potent anticancer and anti-inflammatory function, the potential effect of its new derivatives (SZC014) in human breast cancers has not been understood yet. In this investigation, we demonstrated the anticancer effect of SZC014, a novel OA derivative and identified the possible mechanisms by which SZC014 induced MCF-7 cell death. The biological functions of SZC014 were validated by MTT, migration and colony formation assays in breast cancer cells. Cell apoptosis was monitored by Annexin V- FITC assay. Intracellular ROS and cell cycle were measured by flow cytometric analysis. Western blot was used to detect protein expression level. Our present results fully demonstrated that SZC014 inhibits breast cancer cells proliferation, colony formation, and cell migration. Further investigation verified that ROS generation, apoptosis induction and $\mathrm{G}_{0} / \mathrm{G}_{1}$ phase arrest was observed in SZC014-treated MCF-7 cells. However, pretreatment with N-acetyl- L-cysteine (NAC), a ROS scavenger, increased the expression of procaspase-3. Additionally, SZC014 treatment suppressed the levels of Akt, phosphorylated-Akt (p-Akt), COX-2, p-p65 in the cytoplasmic and p65 in nuclear. Furthermore, the inhibition of p65 nuclear translocation was confirmed by immunofluorescence staining. These data show that SZC014 is an effectively selective anticancer agent against breast cancer cells, highlighting the potential use of this derivative as a breast cancer therapeutic agent.
\end{abstract}

Key words: SZC014, oleanolic acid derivative, apoptosis, breast cancer cells

Breast cancer is one of the most leading causes of cancer death among women worldwide. Nearly 200000 women get diagnosed and about 40000 died of breast cancer every year [1]. Although conventional therapies (surgery, chemoradiotherapy and hormonal therapy) have significantly reduced the risk of disease recurrence and death in breast cancer patients $[2,3]$. The recurrence and metastasis remain a major challenge in the routine clinical setting [4]. Therefore, it is still urgent to develop novel anti-breast cancer drugs to substitute or complement existing ones so as to enhance the therapeutic efficacy.

In the chemotherapy field, natural products have been considered as the main source of chemotherapeutics and are likely to provide more leading structures with enhanced biological activities [5, 6]. A large number of chemo-preventive and chemotherapeutic agents have been discovered from natural products and provided promising approaches to treat and prevent cancer [7]. Triterpenoids are important components of traditional Chinese medicines distributed in a wide range of plants [8]. Oleanolic acid (3b-hydroxyolean-12-en-28-oic acid, OA) is a naturally occurring triterpenoid that exhibits various biological properties such as antibacterial, antiviral, anti-inflammation, anti-hyperlipidemia and anti-cancer, all of which have been studied in vitro or/and in vivo $[9,10]$. However, the disadvantages of $\mathrm{OA}$, such as poor water solubility and low bioavailability, affect their activity. Hence it is a necessary and urgent to carry out the study on the structural modification of OA, for example, it has been reported that several OA derivatives such as CDDO, and its CDDO-Me (methyl ester) and CDDO-Im (imidazolides) exhibit a more effective antitumor activity against many tumor cell lines comparing with OA $[11,12]$. Thus, OA derivatives remain important fields of study in their synthesis and potential anticancer efficacy. 
Aberration of apoptosis has been implicated in carcinogenesis and resistance to conventional anticancer therapies [13]. Thus, promotion of apoptosis in cancer cells with novel agents could lead to tumor regression and improved prognosis. Recently, in order to increase the anti-inflammatory and anticancer activity of oleanolic acid several synthetic analogs have been synthesized. We designed and synthesized a novel derivative of OA, SZC014. Our previous study has shown that SZC014, a new novel derivative of oleanolic acid, which synthesized by us firstly, inhibited the growth of human gastric cancer cell lines by inducing apoptosis and targeting on NF- $\mathrm{\kappa B}$ signaling proteins [14]. However, its effect on other tumor cell lines and its mechanism remains unclear.

Therefore, in this present study, we aimed to examine the anticancer effect of SZC014 on human breast cancer cells in vitro and elucidate the underlying mechanisms. Moreover, we further examined the cell signaling pathway. SZC014 effectively decreased the cell viability of MCF-7 and MDAMB-231 cell lines but has less cytotoxicity in MCF10A cell line. We also confirmed that SZC014 exhibited its anti-tumor activity through inducing cell cycle arrest, anti-inflammation and eventually inducing apoptosis, which was associated with Akt and NF- $\mathrm{kB}$ pathway, increasing the release of reactive oxygen species (ROS) in MCF-7 cells. In this respect, we first reported the potential anticancer effect and mechanisms of SZC014 on human breast cancer cell line MCF-7. These results may provide further support for SZC014 as a novel chemotherapeutic agent for MCF-7 and provide novel insights into the mechanisms underlying the anticancer effects of SZC014 against the human breast cancer cell.

\section{Materials and methods}

Chemicals. Human breast cancer cell lines MCF-7 and MDA-MB-231, and human mammary epithelial cells MCF10A were obtained from Shanghai Institute of Biochemistry and Cell Biology. Dulbecco's modified Eagle medium (DMEM), DMEM/F-12 medium, and fetal bovine serum (FBS) were purchased from Gibco-BRL (Grand Island, NY, USA). The Reactive Oxygen Species Assay Kit, Cell Cycle and Apoptosis Analysis Kit, and Nuclear and Cytoplasmic Extraction kit were obtained from Beyotime Institute of Biotechnology (Haimen, Jiangsu, China). 3-(4, 5-Dimethylthiazol-2-yl)-2,5-diphenyltetrazolinum bromide (MTT), penicillin, streptomycin, and N-Acetyl-LCysteine (NAC) were obtained from Sigma-Aldrich (St Louis, MO, USA). The primary antibodies against $\beta$-Actin, Histone, Akt, p-Akt, procaspase-9, procaspase-3, PARP cleavage, Bax, Bcl-2, were purchased from Proteintech (Chicago, IL, USA). Antibodies against p65, p-p65, and all the secondary antibodies were obtained from Abbkine (Redlands, California, USA).

Cell culture. Human breast cancer cell line MCF-7 and MDA-MB-231 were purchased from the Institute of Biochemistry Cell Biology (Shanghai, China). Cells were cultured in high-glucose DMEM containing 10\% fetal bovine serum, 100units/ml penicillin and $100 \mu \mathrm{g} / \mathrm{ml}$ streptomycin. All cells cultures were maintained at $37^{\circ} \mathrm{C}$ in a humidified atmosphere containing $5 \% \mathrm{CO}_{2}$.

Cell viability assay. Cell viability was determined by a MTT assay. Human breast cancer cells were seeded at $6 \times 10^{3}$ cells/ well in 96-well plates and then cultured for $24 \mathrm{~h}$. After the cells had been cultured for 24 hours, the tested medicines were added into the cell in all experimental process. The cells were changed to fresh medium containing various concentrations of SZC014. After $24 \mathrm{~h}$ incubation, the growth of cells was measured. Then the cells were treated with $15 \mu \mathrm{l}$ MTT stock solution $(5 \mathrm{mg} / \mathrm{ml})$ was added into each well. Four hours later, the formazan crystals were dissolved in dimethyl sulfoxide, and the absorption values were determined at $570 \mathrm{~nm}$ using a microplate reader (Multiskan MK3; Shaanxi Pioneer Biotech Co., Ltd., Xi'an, China).

In vitro migration assay. Cell migration was detected by scratch assay (wound healing assay). The scratch assay is a straightforward and economical method to study cell migration. The cells were grown to full confluence in six-well plates, and then wounded with a 100ul sterile pipette tip after $6 \mathrm{~h}$ of serum starvation. Cells were treated with indicated doses of SZC014 in full medium and kept in a $\mathrm{CO}_{2}$ incubator. After $24 \mathrm{~h}$, the cells were washed with PBS, the wound gap was observed, and cells were photographed using the inverted fluorescence microscope.

Colony formation assay. To analyze the cell sensitivity to SZC014, we used a colony formation assay in vitro. Briefly, MCF-7 cells (per well) were seeded in six-well plates containing $1 \mathrm{ml}$ growth medium with $10 \% \mathrm{FBS}$ and cultured for $24 \mathrm{~h}$. Then, removed the medium, and cells were exposed to various concentrations of SZC014 $(0,5,15 \mu \mathrm{M})$. After $24 \mathrm{~h}$, cells were washed with PBS and supplemented with fresh medium containing 10\% FBS. The cultures were maintained in a $37^{\circ} \mathrm{C}, 5 \% \mathrm{CO}_{2}$ incubator for 14 days, allowing viable cells to grow into macroscopic colonies. Removed the medium, and the colonies were counted after staining with $0.1 \%$ crystal violet.

Transmission electron microscopy. MCF-7 cells were seeded in 6-well plates, incubated at $37^{\circ} \mathrm{C}$ and treated with SZC014 for 24 h. Cells were harvested, collected and fixed overnight at $4{ }^{\circ} \mathrm{C}$ in $2 \%$ glutaraldehyde. The samples were then post-fixed, dehydrated, embedded, sectioned, and stained as previously described [15]. Finally, the electron micrographs were captured using a Transmission Electron Microscope (JEM-2000EX; JEOL Co; Japan).

Apoptosis assay. Apoptosis was measured by fluorescenceactivated cell sorter (FACS) using the Annexin V-FITC Apoptosis Detection Kit. In brief, cells plated in 6-well plates were treated with different concentrations of SZC014 for $24 \mathrm{~h}$. The cell subsequently stained simultaneously with FITClabeled annexin V and PI. Finally, the samples were analyzed using FACS Accuri C6 (Genetimes Technology Inc.).

Cell cycle analysis. To evaluate the cell cycle distribution after exposure to SZC014, the cells were treated with differ- 
ent concentrations of SZC014 for $24 \mathrm{~h}$. After the treatment, the cells were collected and fixed with $70 \%$ cold ethanol overnight at $4^{\circ} \mathrm{C}$. According to the manufacturer's instructions, PI staining reagent $(50 \mathrm{mg} / \mathrm{ml} \mathrm{PI}$ and $1 \mathrm{mg} / \mathrm{ml} \mathrm{RNAse}$ in $1 \mathrm{ml}$ of sodium citrate buffer, $\mathrm{pH}$ 7.4) was prepared, and the samples were then suspended with the reagent in the dark at $37^{\circ} \mathrm{C}$ for $30 \mathrm{~min}$. The cell cycle distribution was detected using FACScan flow cytometry (BD FACSAria II; BD Co; America), and the data were analyzed using the multicycle program from Phoenix Flow Systems (San Diego, CA, USA).

Intracellular ROS accumulation detection. The effect of SZC014 on ROS production in Human breast cancer cell was determined using a fluorometric assay using 2,7-dichlorodihydrofluorescein diacetate (DCFH-DA) as a probe for the presence of ROS. According to the manufacturer's instructions, the cells were treated with different concentrations of SZC014 for $24 \mathrm{~h}$. After the treatment, then the cells were harvested and incubated with DCFH-DA at $37^{\circ} \mathrm{C}$ for $20 \mathrm{~min}$ and washed twice with PBS. After washing twice with PBS, cells were observed under a FACScan flow cytometry $(\mathrm{Ex}=$ $488 \mathrm{~nm}, \mathrm{Em}=530 \mathrm{~nm}$ ), (BD FACSAria II; BD Co; America). Data was analyzed with Cell Quest software.

Immunofluorescence staining for p65 localization. Immunofluorescence staining was made in cells cultured in chamber slides. After SZC014 treatment for $24 \mathrm{~h}$. The cells were washed with PBS and fixed for $10 \mathrm{~min}$ at room temperature (RT) with $4 \%$ paraformaldehyde. The samples were permeabilized with $0.2 \%$ TritonX-100 for $5 \mathrm{~min}$. And then blocked with $15 \%$ bovine serum albumin (BSA) in PBS for $30 \mathrm{~min}$. Antibodies against p 65 in the $1 \%$ blocking solution were added to the sample and incubated for overnight at $4{ }^{\circ} \mathrm{C}$. Following three $10 \mathrm{~min}$ washes with PBS, fluorescein isothiocyanate-and rhodamine-conjugated secondary antibodies were added in $1 \%$ blocking solutions and incubated for $1 \mathrm{~h}$. Subsequently, the stained samples were mounted with DAPI $(1 \mu \mathrm{g} / \mathrm{ml}$ for 10 $\mathrm{min}$ ) to stain cell nuclei. After five additional $5 \mathrm{~min}$ washes, samples were examined with a fluorescence microscope (CKX4, OLYMPUS, Japan).

Western blot analysis. Cell lysate proteins were separated by electrophoresis on a $7.5-12 \%$ sodium dodecyl sulfatepolyacrylamide minigels (SDS-PAGE) and then electrically transferred onto a polyvinylidene difluoride (PVDF) membrane. Western blots were probed with the specific antibodies. The membranes were then visualized using enhanced chemiluminescence reagent with LabWorks software (UVP, Upland, CA, USA). Analogous experiments were performed at least three times.

Statistical analysis. All the data were performed using Graph Pad Prism 5 (Graph Pad Software, Inc., San Diego, CA) and expressed as means $\pm \mathrm{SD}$. Statistical evaluations of the post hoc multiple group comparisons were conducted using the one-way ANOVA. Bonferroni test was used for statistical analysis and the $\mathrm{P}$ value $<0.05$ was considered statistically significant.

\section{Results}

Effect of SZC014 on the cell viability and cell morphology of breast cancer cells. The chemical structures of SZC014 and $\mathrm{OA}$ were depicted in Figure 1.To identify the cytotoxic effect of SZC014 in breast cancer cells, MDA-MB-231, MCF7 cells and MCF10A mammary epithelial cell were treated with increasing concentration of SZC014. Cell viability was determined by MTT assay (Figure 2A). The result showed that SZC014 decreased the cell viability of the MCF-7 and MDA-MB-231 cell lines in a dose and time-dependent manner. But showed less toxic to MCF10A mammary epithelial cell line, suggesting that SZC014 was a selective anticancer agent against breast cancer cells. Furthermore, we found that MCF-7 cell line was more sensitive than MDA-MB-231 cell line in response to SZC014 treatment, although SZC014 was able to decrease the cell viability of both breast cancer cell lines. The 50\% inhibitory concentration $\left(\mathrm{IC}_{50}\right)$ after $24 \mathrm{~h}$ of SZC014 treatment was $9.8 \mu \mathrm{M}$ in MCF-7 cells and $11.2 \mu \mathrm{M}$ for MDA-MB-231 cells respectively. Moreover, SZC014 treatment could cause a more significant reduction in cell viability in MCF-7 cells, as compared with OA (Fig. 2B), in addition to the same concentration, SZC014 caused a more obvious reduction in cell viability of MCF-7 cells with the increase of incubation time (Figure 2C). These data suggest that SZC014 is a potential selective anticancer agent against breast cancer cells, especially MCF-7 cells.

SZC014 suppressed migration and colony formation of breast cancer cells. As shown in Figure 3A, the part of gap

A<smiles>CC1(C)CC[C@]2(O)CC[C@]3(C)C(=CCC4[C@@]5(C)CC[C@@H](O)C(C)(C)C5CC[C@]43C)C2C1</smiles>

B

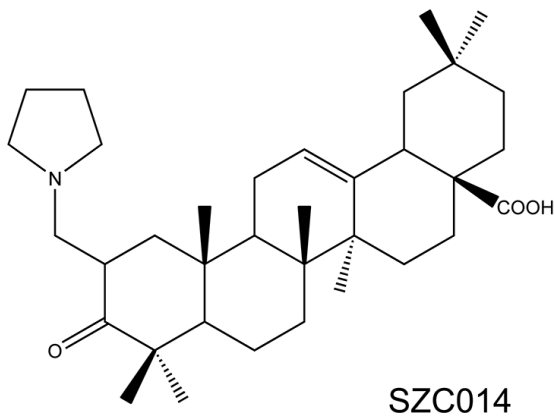

Figure 1. (A) The chemical structure of OA. (B) The chemical structure of SZC014. 
A

B
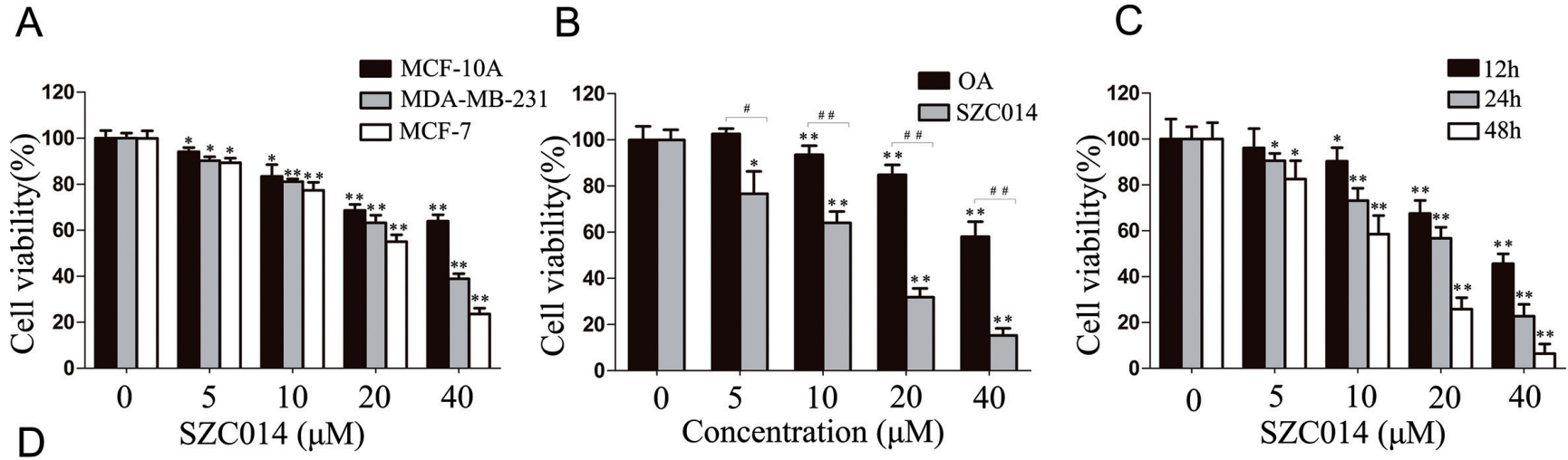

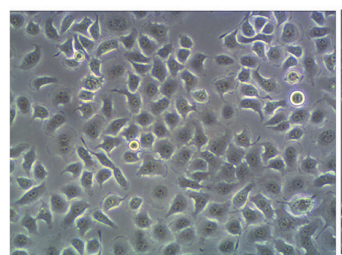

0

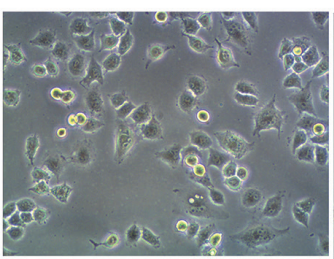

5

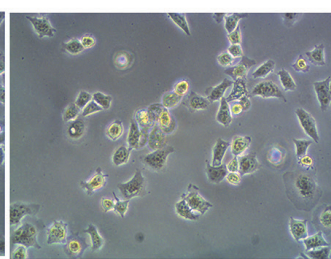

10

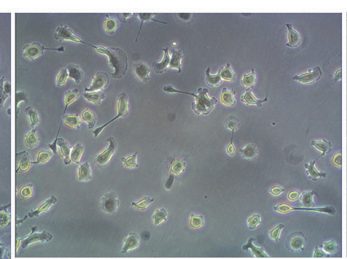

20

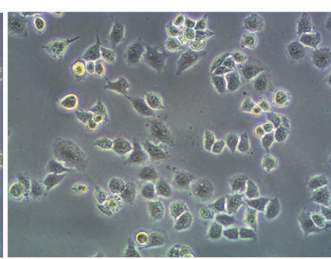

40

\section{SZC014 ( $\mu \mathrm{M})$}

$\mathrm{OA}(\mu \mathrm{M})$

Figure 2. SZC014 inhibited cell viability and changed morphology. (A) The inhibition effect of SZC014 on MCF-10A, MCF-7, and MDA-MB-231 cell lines. Cells were treated with SZC014 at concentrations ranging from 5 to $40 \mu \mathrm{M}$ and cell viability was measured by the MTT assay after treatment for $24 \mathrm{~h}$. The values were expressed as mean \pm SD of 3 independent experiments. ${ }^{\star}$ Significantly different from control group, ${ }^{*} p<0.05,{ }^{* *} p<0.01$. (B) The inhibition effect of SZC014 and OA on cell viability in MCF-7 cells. The values were expressed as mean \pm SD of 3 independent experiments. ${ }^{\star}$ Significantly different from control group, ${ }^{\star} p<0.05$, ${ }^{* *} p<0.01$. Significant differences between SZC014 treatment groups and OA treatment groups ${ }^{*} p<0.05,{ }^{* *} p<0.01$. (C) The concentration and time-dependent effect of SZC 014 on MCF-7 cells. The values were expressed as mean \pm SD of 3 independent experiments. ${ }^{*}$ significantly different from control, ${ }^{\star} p<0.05,{ }^{* *} p<0.01$. (D) Inverted contrast phase microscopy showed morphology changes of MCF-7 cells treated with SZC014 (5, 10 and $20 \mu \mathrm{M})$ and OA $(40 \mu \mathrm{M})$ for $24 \mathrm{~h}$.

A

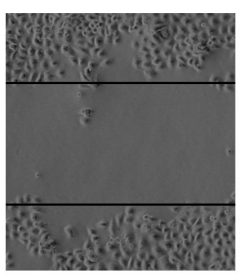

$0 \mu \mathrm{M}$ Oh

B

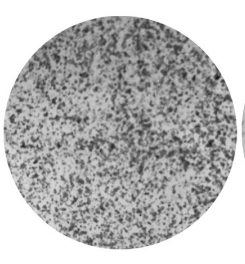

$0 \mu \mathrm{M}$

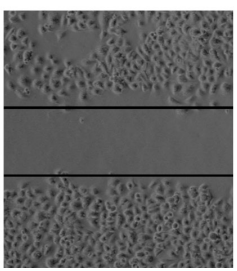

$0 \mu \mathrm{M} 24 \mathrm{~h}$

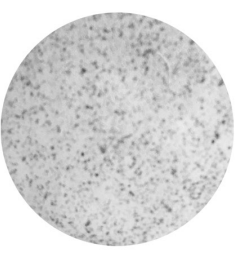

$5 \mu \mathrm{M}$

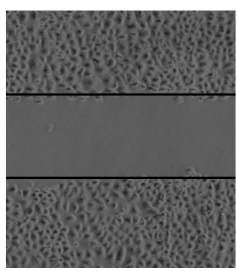

$5 \mu \mathrm{M} 24 \mathrm{~h}$

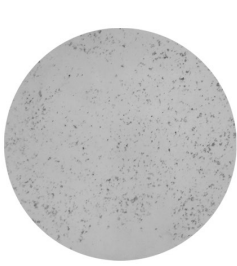

$10 \mu \mathrm{M}$

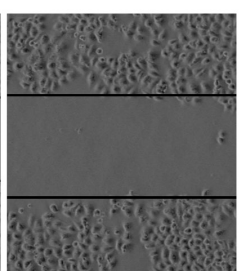

$10 \mu \mathrm{M} 24 \mathrm{~h}$

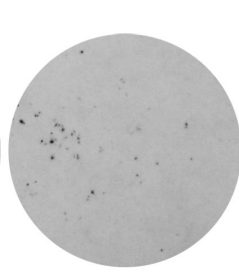

$15 \mu \mathrm{M}$
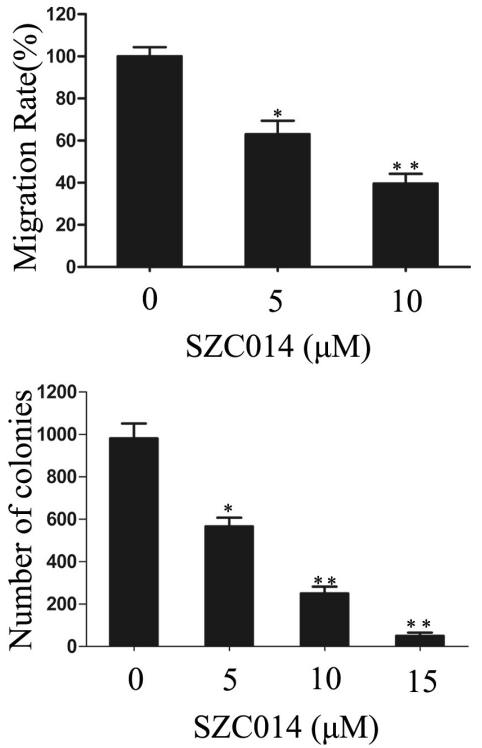

Figure 3. SZC014 suppressed cell migration and colony formation. (A) Cell migration was analyzed by a wound-healing assay. MCF-7 cells were seeded in 6-well plates and grown to full confluence. Cell migration was measured and the migration rate was calculated. (B) The tumor cell MCF-7-induced colony formation was also analyzed, and the colony formation rate was calculated. The data were presented as the mean \pm SD of 3 independent experiments. $\left({ }^{*} p<0.05,{ }^{* *} p<0.01\right.$, significant differences from control groups). 
or wounding space between cell layers after making a scratch was occupied almost (in MCF-7 cells) by the migrating cells after $24 \mathrm{~h}$ in the control group. By contrast, the SZC014 treated cells failed to occupy the scraped space through migration due to their impaired migration capability. Quantitative analysis revealed that the inhibition of migration was in a dose-dependent manner. Clonogenic cell survival assay was employed to evaluate the influence of SZC014 on the clonogenic capacity of MCF-7 cells. Consistent with cell proliferation inhibition, SZC014 also significantly inhibited colony formation and resulted in a remarkable decrease in colony formation ratio (Figure 3B). These results suggest that SZC014 has the perfect properties in suppressing cell migration and colony formation for MCF-7 cells.

SZC014 induces apoptosis in the breast cancer cells. Morphological changes of apoptosis, including cell shrinkage and fragmentation, were observed in the MCF-7 after treatment with SZC014 (Figure 2D). The induction of apoptosis in SZC014 treated, the MCF-7 cells were analyzed by using flow cytometry. After treatment with different con-
A

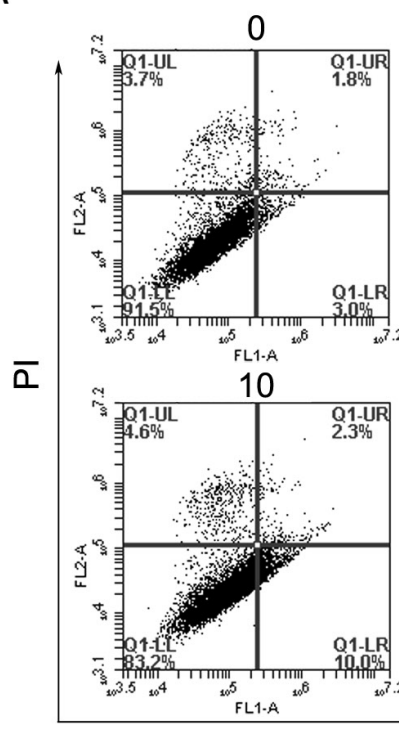

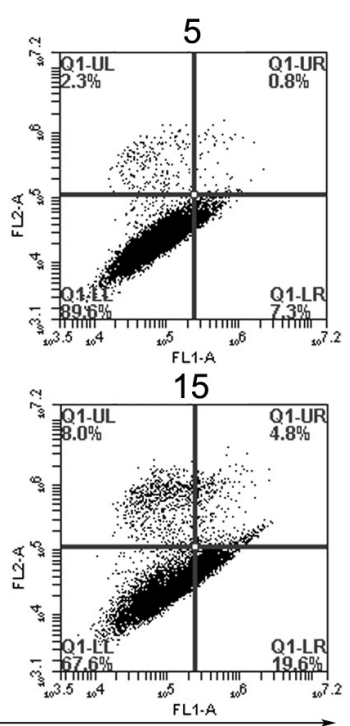

AV
C

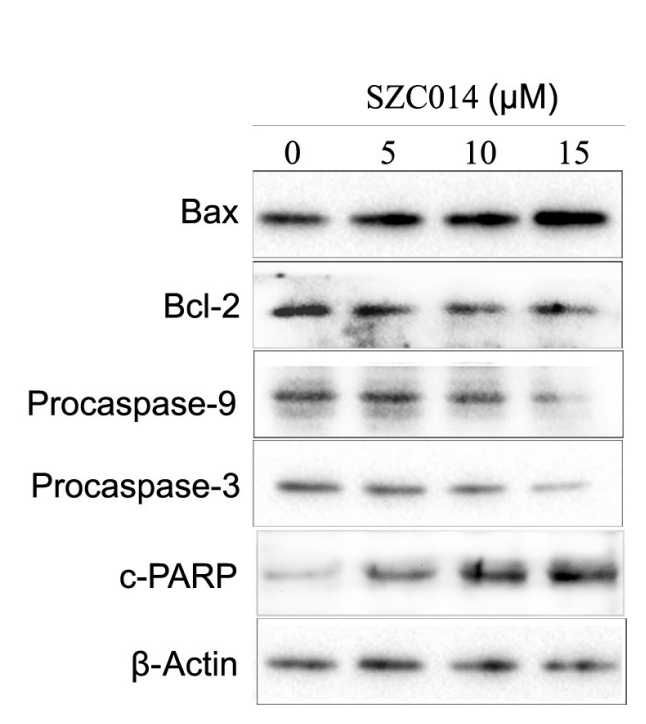

C
B

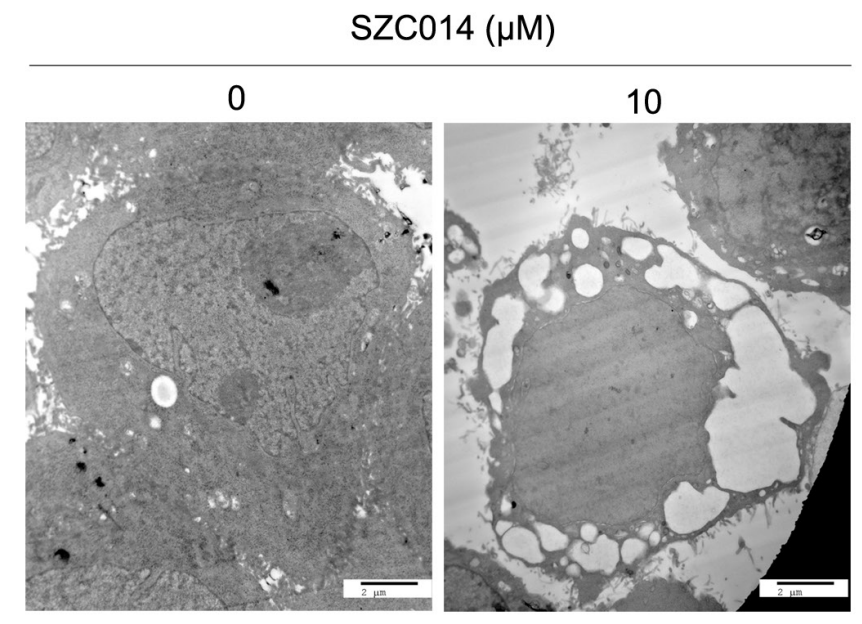

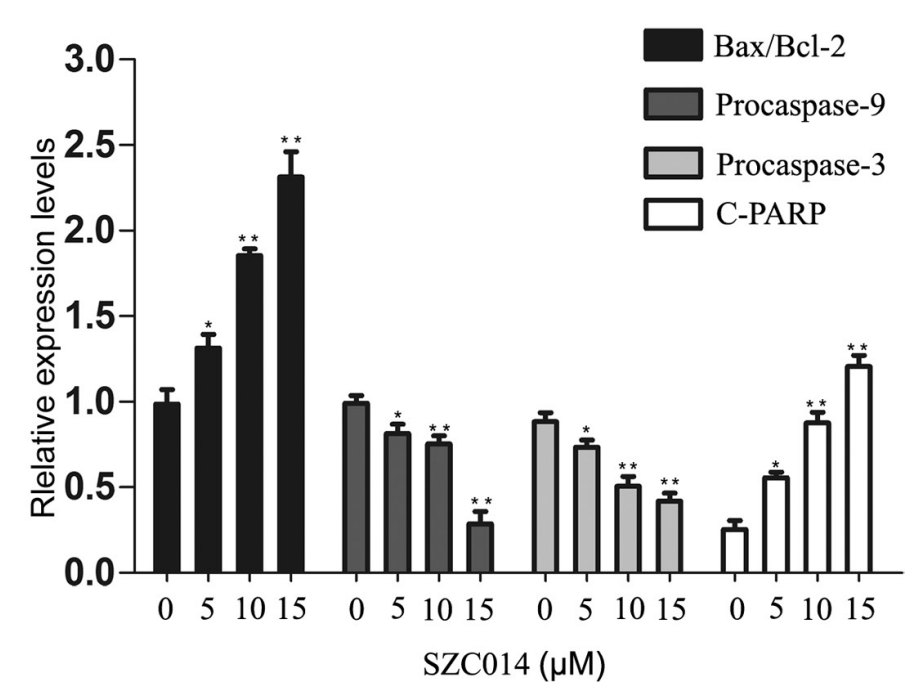

Figure 4. Apoptosis induction of SZC014 in the MCF-7 cells. (A) Flow cytometric analysis of the apoptosis induction of SZC014 in the MCF-7 cells. After treatment with SZC014 at concentrations of 5, 10 and $15 \mu \mathrm{M}$ for $24 \mathrm{~h}$, the cells were then stained with Annexin V-FITC and PI then analyzed by flow cytometry. (B) Transmission electron microscopy shows the occurrence of apoptosis in MCF-7 cells after treatment with $10 \mu \mathrm{M}$ SZC014 for $24 \mathrm{~h}$. (C) Western blot analysis was performed to determine the apoptosis pathway induced by SZC014 in the MCF-7 cells. Cells were treated with different concentrations of SZC014 $(5,10$ and $15 \mu \mathrm{M})$ for $24 \mathrm{~h}$. The values were expressed as mean \pm SD of 3 independent experiments. ${ }^{\star}$ Significantly different from control, ${ }^{\star} p<0.05,{ }^{\star *} p<0.01$. 
Concentration $(\mu \mathrm{M})$

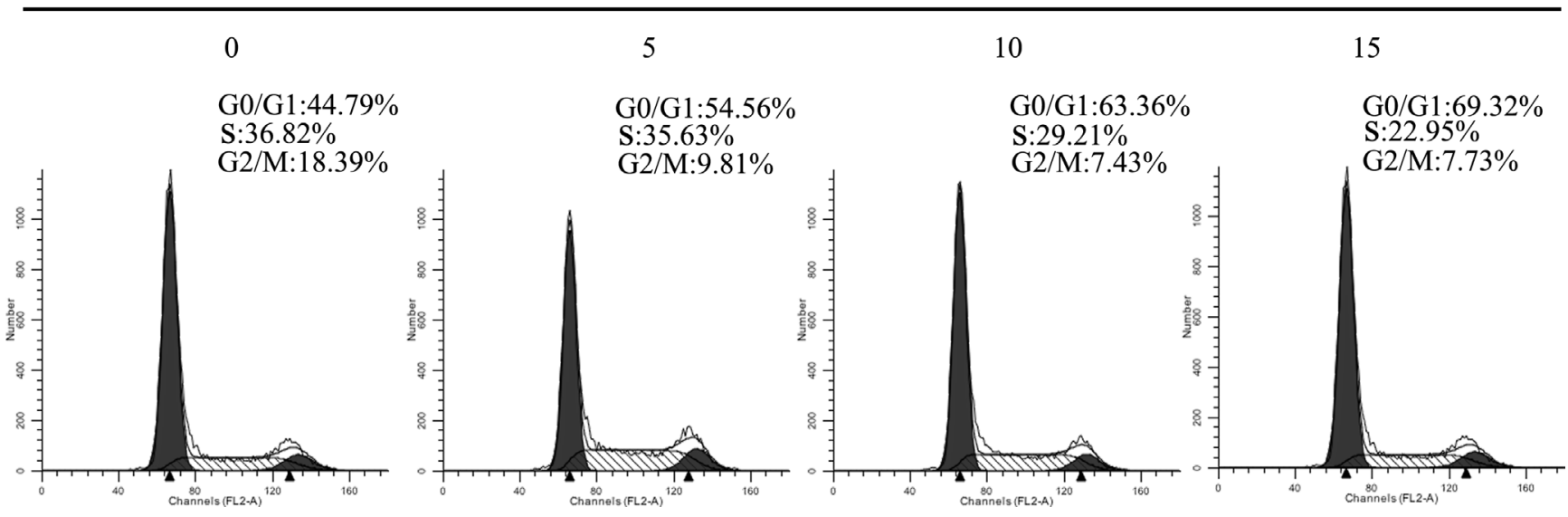

Figure 5. Analysis of the cell cycle distribution of SZC014-treated MCF-7 cells. Cells were treated with different concentrations of SZC014 (5, 10, and $15 \mu \mathrm{M}$ ) for $24 \mathrm{~h}$, and cell cycle distribution was then analyzed by flow cytometry.

centrations of SZC014 for $24 \mathrm{~h}$, the total apoptotic ratio was increased from 8.1 to $24.4 \%$ in the MCF-7 cells (Figure 4A). We found that SZC014 induced apoptosis in MCF-7 cells in a concentration-dependent manner (Figure 4A). Transmission electron microscopy showed the occurrence of apoptosis that was induced by SZC014 in MCF-7 cells after treatment with $10 \mu \mathrm{M}$ SZC014 for $24 \mathrm{~h}$ (Figure 4B). As expected, the ratio of $\mathrm{Bax} / \mathrm{Bcl}-2$, which determines the susceptibility to apoptosis by regulating mitochondrial functions [16] was increased by SZC014 (Figure 4C). The levels of procaspase- 9 and procaspase- 3 were suppressed by SZC014, and the PARP cleavage was increased by SZC014. Enhanced apoptosis was significantly by SZC014 in a dose-dependent manner. Our data indicated that the inhibition of viability of MCF-7 cells by SZC014 is due to its capacity of induction of intrinsic apoptosis.

Effect of SZC014 on cell cycle distribution of MCF-7 cells. Cell cycle arrest is an important mechanism that inhibits cancer cell growth [17]. Our results revealed that SZC014 treatment caused an accumulation of MCF-7 cells in the $\mathrm{G}_{1}$-phase. As shown in Figure 5, the percentage of cells in the $G_{1}$-phase was increased from $44.79 \%$ in the control group to $69.32 \%$ in the $15 \mu \mathrm{M}$ SZC014 group. Our findings suggest that SZC014 induced $\mathrm{G}_{1}$-phase arrest of the MCF-7 cells.

Akt is the target of SZC014 in MCF-7 cells. Akt is a major anti-apoptotic signaling pathway, and previous studies have demonstrated that chemotherapeutic agents induced cancer cell apoptosis via inhibiting the Akt pathway $[18,19]$. As we expected, SZC014 could significantly suppress the expression of both Akt and p-Akt which is an active form of Akt in a concentration-dependent manner (Figure 6A, 6B). These data suggest that Akt pathway might be an effective target for SZC014 in MCF-7 cells.

The COX-2 signaling pathway is the target of SZC014 in MCF-7 cells. Cyclooxygenase-2 (COX-2) is one of the isoforms of cyclooxygenase, a rate-limiting enzyme in the
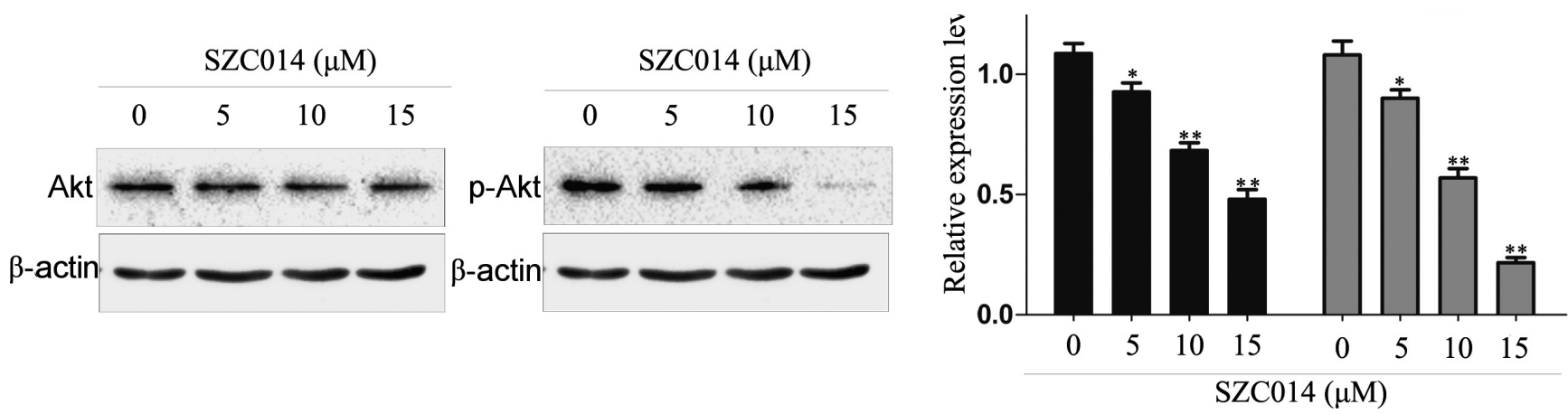

Figure 6. Western blot analysis of Akt and p-Akt in response to SZC014 treatment in MCF-7 cells. Treatment (24 h) of MCF-7 cells withSZC014 (5, 10 , and $15 \mu \mathrm{M})$ resulted in the suppression of both Akt and p-Akt. The values were expressed as mean \pm SD of 3 independent experiments. ${ }^{\star}$ Significantly different from control, ${ }^{*} p<0.05,{ }^{* *} p<0.01$. 
arachidonic acid cascade. High expression of COX-2 is implicated in cancer cell growth, migration and angiogenesis [14, 20]. To determine the effects of SZC014 on COX-2 signaling in breast cancer cells, we next analyzed the expression of COX-2 protein in MCF-7 cells treated with SZC014 by Western blot. Treatment with SZC014 significantly inhibited COX-2 protein expression in a concentration-dependent manner (Figure 7A).
The NF- $\kappa \mathrm{B}$ signaling pathway is the target of SZC014 in MCF-7 cells. To evaluate whether SZC014 inhibited the apoptosis responses through NF- $\kappa \mathrm{B}$ in MCF-7 cells, we focused our attention on assessing the level of several NF- $\kappa$ B pathway-related proteins namely p-p65 in cytoplasm and p65 in nucleus. As shown in Figure 7B and 7C, SZC014 significantly suppressed the expression of p-p65 in cytoplasm and p65 in nucleus. To determine whether $\mathrm{p} 65$ nuclear translocation could be inhibited
A
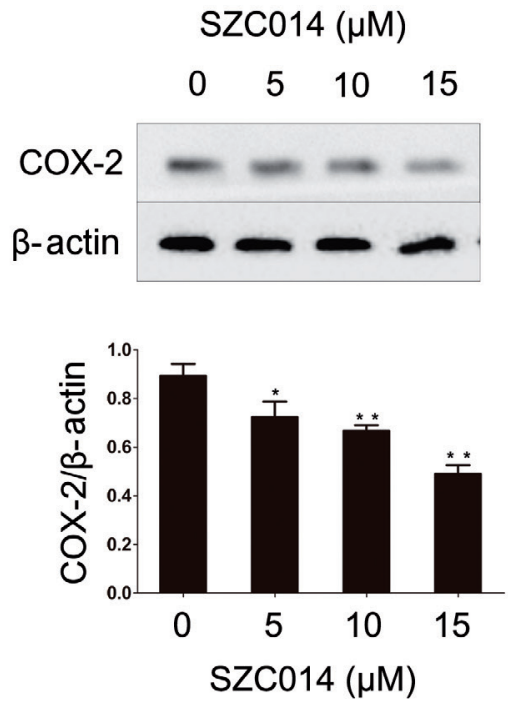

B
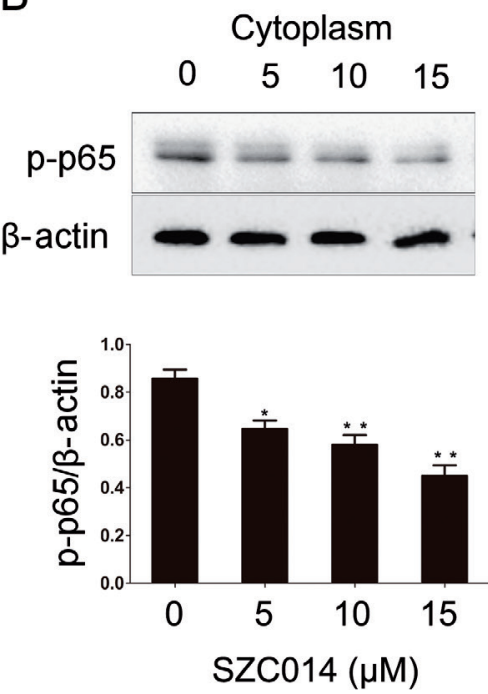

C
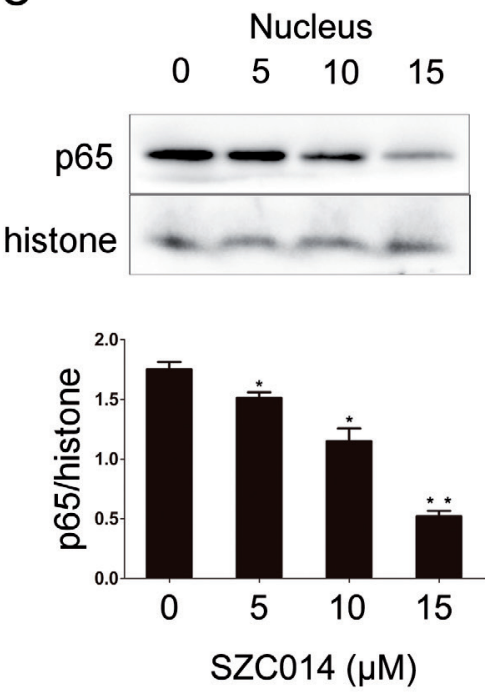

$\mathrm{D}$

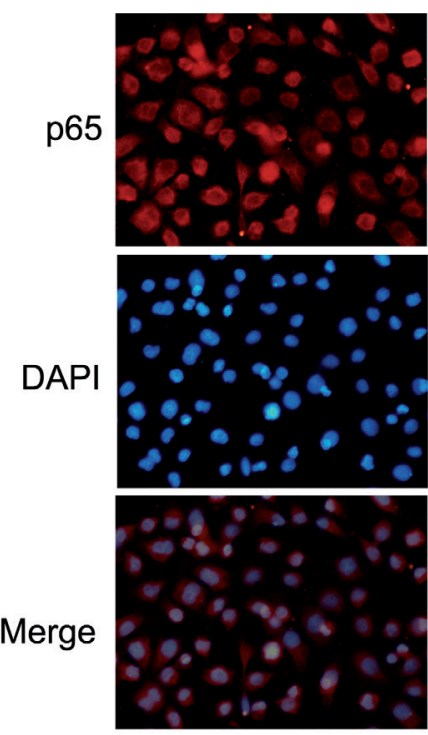

0
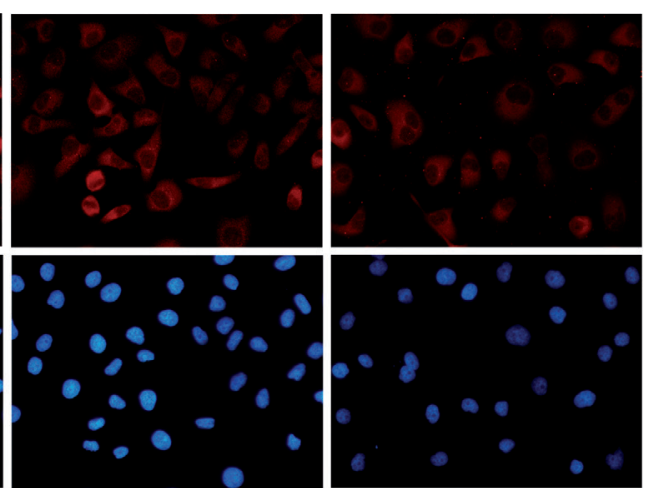

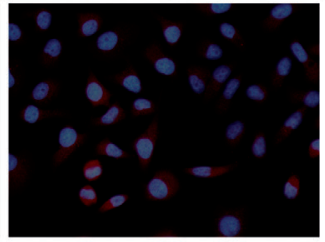

5

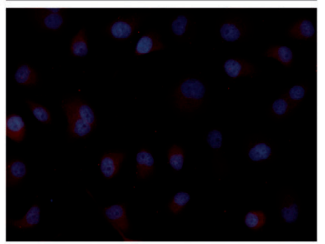

15

\section{$\operatorname{SZC014}(\mu \mathrm{M})$}

Figure 7. Inhibition effect of SZC014 on the COX-2/NF- $\mathrm{kB}$ pathway. (A) Western blot analysis of COX-2 protein. (B, C) Western blot analysis of NF-kB pathway related proteins, including cytoplasm p-p65 and nucleus p-65. (D) Immunofluorescence staining analysis of p65 localization. MCF-7 cells treated with SZC014 (5 and $15 \mu \mathrm{M})$ for $24 \mathrm{~h}$ were labeled for $\mathrm{p} 65$ (red), and nuclei were stained with DAPI (blue). The values were expressed as mean \pm SD of 3 independent experiments. ${ }^{\star}$ Significantly different from control, ${ }^{*} p<0.05,{ }^{* *} p<0.01$. 
by SZC014, immunofluorescence analysis was performed. The data indicated that $\mathrm{p} 65$ nuclear translocation was inhibited by SZC014 with the increase of concentration (Figure 7D).

Effects of ROS generation in SZC014 induced breast cancer cells. SZC014 induced intracellular ROS generation was evaluated using intracellular peroxide-dependent oxidation of DCFH-DA to form fluorescent DCF. DCF fluorescence was detected after cells were treated with 5-15 $\mu \mathrm{M} \mathrm{SZC014}$ for $24 \mathrm{~h}$. ROS production was considerably increased under inducement with 5-15 $\mu \mathrm{M}$ SZC014 in a dose-dependent manner (Figure $8 \mathrm{~A})$. In order to further determine SZC014 influence on ROS generation, this study introduced the active oxygen scavenger n-acetyl-L-cysteine (NAC), as a positive control. As shown in Figure $8 \mathrm{~B}$, pre-treatment with NAC could prevent excessive ROS generation. To further delineate the role of ROS in the induction of apoptosis by SZC014, we measured the level of procaspases-3, by SZC014 in cells pretreated with NAC. The result showed that NAC prevented apoptosis induced by SZC014 (Figure 8C).

\section{Concentration $(\mu \mathrm{M})$}
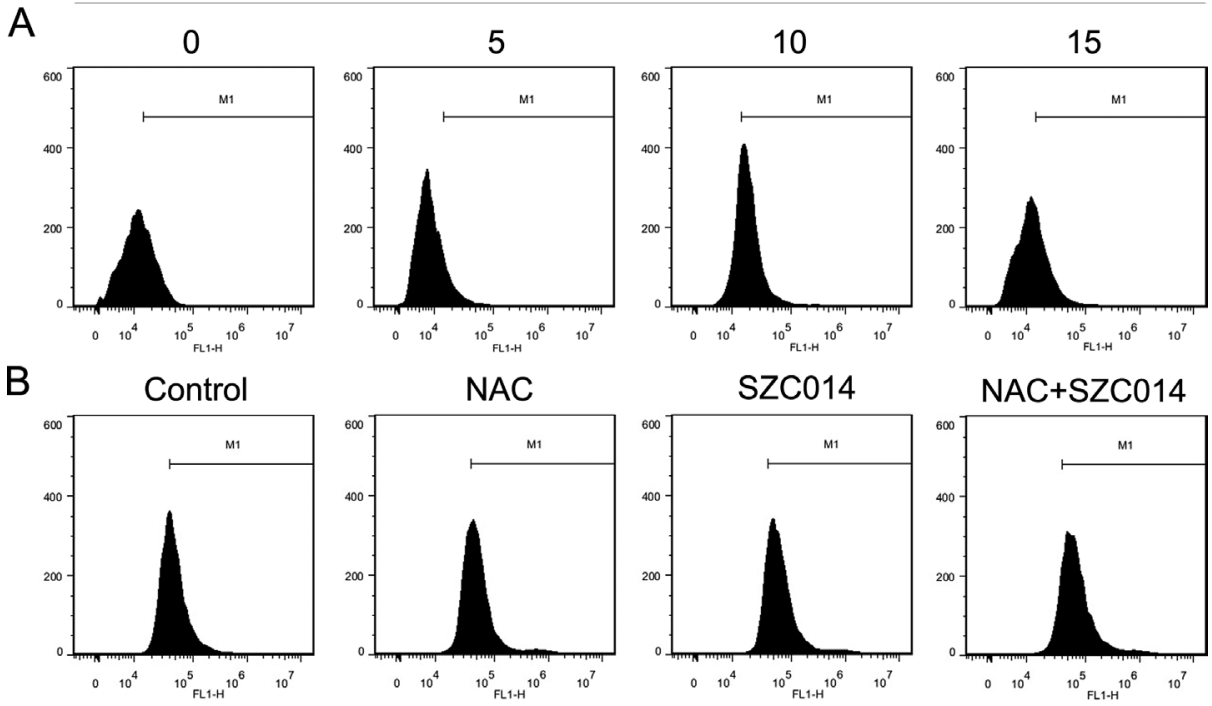

C

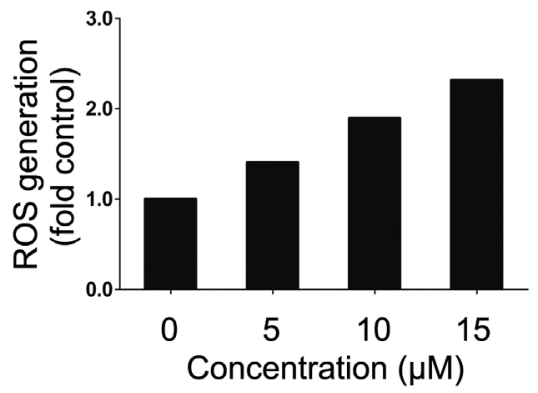

E

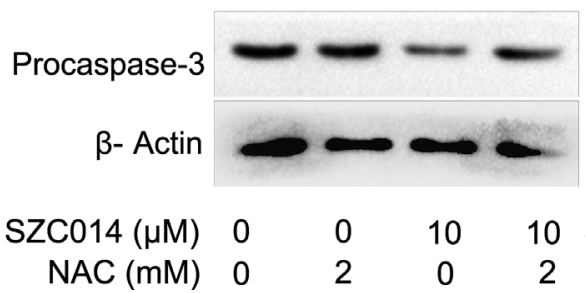

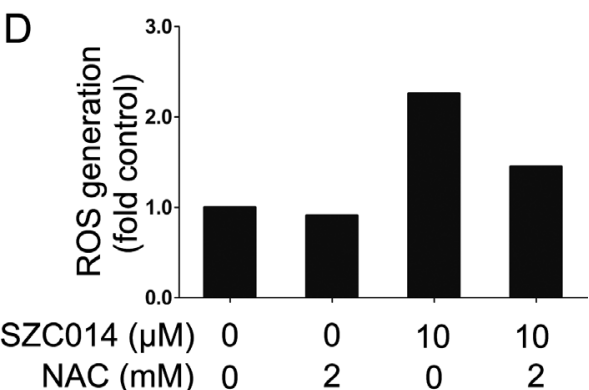

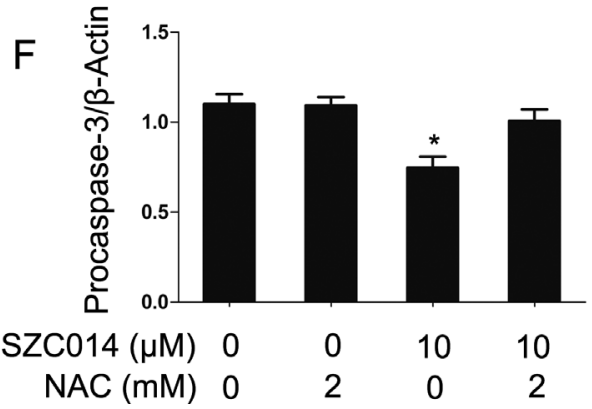

Figure 8. Effect of SZC014 on intracellular ROS generation. (A, C) SZC014 increased the intracellular ROS generation in MCF-7 cells. Cells were treated with SZC014 at concentrations of 5, 10, and $15 \mu \mathrm{M}$ for $24 \mathrm{~h}$, and then the level of intracellular ROS was detected by flow cytometry. (B, D) Effect of excessive ROS generation in SZC014-treated MCF-7 cells. Cells were pretreated with $2 \mathrm{mM}$ NAC for $1 \mathrm{~h}$ and then treated with $10 \mu \mathrm{M}$ SZC014. At $24 \mathrm{~h}$ after treatment, ROS production was measured by flow cytometry. (E, F) Western blot analysis of procaspase-3 after pretreatment with $2 \mathrm{mM}$ NAC for 1 h. The values were expressed as mean \pm SD of 3 independent experiments. ${ }^{\star}$ Significantly different from control, ${ }^{\star} p<0.05,{ }^{\star *} p<0.01$. 


\section{Discussion}

OA and its derivatives have been shown to exhibit an inhibitory effect on tumor growth in vivo and induce apoptosis in human breast cancer cells $[21,22]$. The present study demonstrated that SZC014, a novel derivative of OA with improved stability and water solubility, effectively inhibited breast cancer cells growth and enhanced apoptosis induction dose-dependently, as compared with OA. While SZC014 had less an antiproliferative effect on normal breast cells MCF10A. It has been confirmed that cancer cell lines or normal cell line possessed different responses to similar drug because of their different hereditary background. For instance, MCF-7 cell line is characterized by estrogen receptor (ER) positive/ progesterone receptor (PR) positive/HER-2 positive ("triple positive"), while MDA-MB-231 cell line is characterized by Ernegative/PR-negative/HER-2 negative ("triple negative") [23]. Interestingly, our study showed that these two cell lines also possessed different responses to SZC014. Furthermore, the present study showed that the effect of SZC014 on breast cancer in which, excessive intracellular ROS generation leads to PI3K/Akt and NF-kB/COX-2 signaling pathway suppression and subsequent induction of apoptosis.

Apoptosis, otherwise known as programmed cell death, regulates the process that maintains the balance of cell numbers in multicellular organisms [24]. The induction of apoptosis is one of the most effective approaches in cancer therapeutics [25]. To determine whether SZC014-induced cell death in breast cancer cells is associated with apoptosis, we performed flow cytometric analysis. As shown in Fig. 4, SZC014 induced apoptosis in a concentration dependent manner in MCF-7 cells. It is usually considered that two major pathways of apoptotic cell death program have been identified, namely receptormediated (extrinsic) and mitochondrial (intrinsic) apoptotic cell death pathways [11]. The mitochondrial apoptotic pathway plays an important role in inducing apoptosis via activation of pro-apoptotic molecules such as Bax leading to activation of caspase [26]. An induction of caspase-3 activation causes the cleavage or degradation of several important substrates, and then also lead to activation of caspase-9, a cross-talk exists between the death receptor and mitochondrial pathways $[27,28]$. Our results were similar to the previous studies that OA induced apoptosis in some cancer cell types mainly by the mitochondrial apoptosis pathway $[29,30]$. The ratio of Bax/ $\mathrm{Bcl}-2$ and the expression of PARP cleavage were significantly increased (Fig. 4C), indicating that the mitochondria were severely damaged by SZC014. Moreover, the hallmarks of intrinsic apoptosis proteins, procaspase- 9 and procaspase- 3 were also suppressed by SZC014 in a concentration-dependent manner.

ROS can be generated in various organelles such as by mitochondria (considered the main source of intracellular oxidant production), the peroxisomes and endoplasmic reticulum [31]. It has been proposed that $\mathrm{OA}$ and its derivatives pro-apoptotic effects via generation of ROS in various cancers
$[32,33]$. Furthermore, several studies have demonstrated the role of ROS in mitochondria toxicity by the activation of different mechanisms, including the increase of mitochondrial permeability $(\Delta \Psi \mathrm{m})$ and mitochondrial depolarization, which are dependent on a high level of intracellular calcium, and thus causes apoptotic cell death involving the inhibition of procaspase- 3 in cancer cells $[34,35]$. Our results also confirmed that SZC014 caused high level generation of ROS in MCF-7 cells (Figure 8A), and further verified that apoptosis induced by SZC014 was effectively Inhibited by NAC (Figure 8C), suggesting that ROS might be critical in regulating apoptosis in breast cancer cells.

Cell cycle progression is a complex biological process that includes cell growth and mitosis [36]. Several anticancer drugs lead to DNA damage, resulting in cell cycle modulation [37]. Our results demonstrated that the SZC014-mediated cell cycle arrest resulted in an increase in the proportion of cells in the $\mathrm{G}_{1}$-phase (Figure 5), suggesting that SZC014 led to the abrogation of DNA synthesis and the retardation of cell cycle progression may be one of the mechanisms of the anticancer activity by SZC014.

PI3K/Akt pathway plays a critical role in mediating cell growth, cell cycle progression and apoptosis $[38,39]$. Our results revealed that SZC014 inactivated both Akt and p-Akt in a dose-dependent manner in MCF-7 cells, indicating that the antiproliferative effects of SZC014 might be linked to the inactivation of the Akt pathway. Furthermore, a recent study showed that a novel oleanolic acid derivative presents constitutive activation of NF- $\kappa \mathrm{B}$ signaling pathway and the up-regulation of NF- $\mathrm{KB}$-dependent genes [11]. Increasing evidence has shown that NF- $\mathrm{kB}$ activation is a consequence of the formation of an inflammatory microenvironment during malignant progression $[40,41]$. In addition, NF- $\kappa B$ is considered to be a very important signaling complex that interacts with the Akt pathway $[42,43]$. The tumorigenic functions of NF-kB have been shown to be involved in the activation of Akt by the phosphorylation of p65 subunit [44]. Meanwhile, emerging evidence also indicates that overexpression of p-Akt, $\mathrm{Bcl}-2$, and COX-2 is associated with poor prognosis [45]. Our data indicated that SZC014 inhibited the activation of NF- $\kappa B$ and exerted this effect by the inhibition of the translocation of NF- $\kappa B$ p 65 protein from cell cytoplasm to nucleus. COX-2, an inducible enzyme, can be rapidly induced by inflammatory mediators, growth factors and tumor promoter [46]. The transcription factor NF- $\mathrm{kB}$ has been shown to be involved in the COX-2 expression in various cell types [47]. In addition, previous studies have shown that COX-2 overexpression plays an important role in cancer development by the promotion of cell proliferation, the decrease of apoptosis rate and the increase of invasive and the induction of cell cycle arrest [48]. In this study, our results showed that SZC014 could significantly inhibit the COX-2 expression in MCF-7 cells, investigating COX-2 may play an important role in SZC014 induced bioactive functions, such as the inhibition of breast cancer cells viability, migration and colony formation. 
In conclusion, this study has found that SZC014, a novel OA derivative, exhibits an inhibitory effect on breast cancer through the induction of apoptosis and cell cycle arrest in MCF-7 cells. Our findings indicated that SZC014 induced excessive ROS is the upstream inhibitory molecule of PI3K/ Akt and NF- $\mathrm{kB} / \mathrm{COX}-2$ signaling and thereby triggers apoptosis. However, the effect of SZC014 in other breast cancer cell lines and in vivo, as well as its role in other underlying mechanisms, remains to be further studied.

Acknowledgments: This work was supported by the Natural Science Foundation of China (no. 30772601) and the University Innovation Team Project Foundation of Education Department of Liaoning Province (no. LT2013019).

\section{References}

[1] YANG F, HU M, LEI Q, XIA Y, ZHU Y et al. Nifuroxazide induces apoptosis and impairs pulmonary metastasis in breast cancer model. Cell Death Dis 2015; 6: e1701. https://doi. org/10.1038/cddis.2015.63

[2] HOU ZJ, LUO X, ZHANG W, PENG F, CUI B et al. Flubendazole, FDA-approved anthelmintic, targets breast cancer stem-like cells. Oncotarget 2015; 6: 6326-6340. https://doi. org/10.18632/oncotarget.3436

[3] NIU DG, PENG F, ZHANG W, GUAN Z, ZHAO HD et al. Morphine promotes cancer stem cell properties, contributing to chemoresistance in breast cancer. Oncotarget 2015; 6: 3963-3976. https://doi.org/10.18632/oncotarget.2894

[4] XU J, ZUO D, QI H, SHEN Q, BAI Z et al. 2-Methoxy-5 ((3,4,5 -trimethosyphenyl)seleninyl) phenol (SQ0814061), a novel microtubule inhibitor, evokes G2/M cell cycle arrest and apoptosis in human breast cancer cells. Biomed Pharmacother 2016; 78: 308-321. https://doi.org/10.1016/j. biopha.2016.01.040

[5] MANN J. Natural products in cancer chemotherapy: past, present and future. Nat Rev Cancer 2002; 2: 143-148. https:// doi.org/10.1038/nrc723

[6] FUKUMURA M, ANDO H, HIRAI Y, TTORIIZUKA $\mathrm{K}$, IDA Y et al. Achyranthoside $\mathrm{H}$ methyl ester, a novel oleanolic acid saponin derivative from Achyranthes fauriei roots, induces apoptosis in human breast cancer MCF-7 and MDA-MB-453 cells via a caspase activation pathway. J Nat Med 2009; 63: 181-188. https://doi.org/10.1007/s11418008-0311-7

[7] LIU YZ, WU K, HUANG J, LIU Y, WANG X et al. The PTEN/ $\mathrm{PI} 3 \mathrm{~K} / \mathrm{Akt}$ and Wnt/ $\beta$-catenin signaling pathways are involved in the inhibitory effect of resveratrol on human colon cancer cell proliferation. Int J Oncol 2014; 45: 104-112. https://doi. org/10.3892/ijo.2014.2392

[8] LISIAK N, PASZEL-JAWORSKA A, BEDNARCZYK-CWYNAR B, ZAPRUTKO L, KACZMAREK M et al. Methyl 3-hydroxyimino- 11-oxoolean-12- en-28-oate (HIMOXOL), a synthetic oleanolic acid derivative, induces both apoptosis and autophagy in MDA-MB-231 breast cancer cells. Chem Biol Interact 2014; 208: 47-57. https://doi.org/10.1016/j. cbi.2013.11.009
[9] POllier J, GOOSSENS A. Oleanolic Acid. Phytochemistry 2012; 77: 10-15. https://doi.org/10.1016/j. phytochem.2011.12.022

[10] LIU J, WU N, MA LN, ZHONG JT, LIU G et al. p38 MAPK signaling mediates mitochondrial apoptosis in cancer cells induced by oleanolic acid. Asian Pac J Cancer Prev 2014; 15: 4519-4525. https://doi.org/10.7314/ APJCP.2014.15.11.4519

[11] GAO L, WANG Y, XU Z, LI X, WU J et al. SZC017, a novel oleanolic acid derivative, induces apoptosis and autophagy in human breast cancer cells. Apoptosis 2015; 20: 1636-1650. https://doi.org/10.1007/s10495-015-1179-0

[12] Deeb D, Gao X, LIU YB, GAUTAM SC. Inhibition of cell proliferation and induction of apoptosis by CDDO-Me in pancreatic cancer cells is ROS-dependent. J Exp Ther Oncol 2012; 10: 51-64.

[13] KERR JF, WINTERFORD CM, HARMON BV. Apoptosis. Its significance in cancer and cancer therapy. Cancer 1994; 73: 2013-2026, https:// doi.org/10.1002/1097-0142(19940415)73:8<2013::AIDCNCR2820730802>3.0.CO;2-J

[14] LI XR, SONG YS, WU JJ, CHEN ZM, SUN ZW et al. The dual induction of apoptosis and autophagy by SZC014, a synthetic oleanolic acid derivative, in gastric cancer cells via NF- $\kappa B$ pathway. Tumour Biol 2016; 37: 5133-5144. https:// doi.org/10.1007/s13277-015-4293-2

[15] WEN YD, WANG H, KHO SH, RINKIKO S, SHENG X et al. Hydrogen sulfide protects HUVECs against hydrogen peroxide induced mitochondrial dysfunction and oxidative stress. PLoS One 2013; 8: e53147. https://doi.org/10.1371/ journal.pone.0053147

[16] LI Q, LI X, WANG C. Uc.206 regulates cell proliferation and apoptosis by targeting P53 in cervical cancer cells. Neoplasma 2016; 63: 411-418. https://doi. org/10.4149/310 151017N538

[17] JING X, CHENG W, WANG S, LI P, HE L. Resveratrol induces cell cycle arrest in human gastric cancer MGC803 cells via the PTEN-regulated PI3K/Akt signaling pathway. Oncol Rep 2016; 35: 472-478.

[18] QIU P, GUAN H, DONG P, LI S, HO CT et al. The p53-, Baxand p21-dependent inhibition of colon cancer cell growth by 5-hydroxy polymethoxyflavones. Mol Nutr Food Res 2011; 55: 613-622. https://doi.org/10.1002/mnfr.201000269

[19] SHEPPARD K, KINROSS KM, SOLOMON B, PEARSON RB, PHILLIPS WA. Targeting PI3 kinase/AKT/mTOR signaling in cancer. Crit Rev Oncog 2012; 17: 69-95. https://doi. org/10.1615/CritRevOncog.v17.i1.60

[20] YU Z, GUO W, MA X, ZHANG B, DONG P et al. Gamabufotalin, a bufadienolide compound from toad venom, suppresses COX-2 expression through targeting IKK $\beta / N F-\kappa B$ signaling pathway in lung cancer cells. Mol Cancer 2014; 13: 1-14. https://doi.org/10.1186/1476-4598-13-203

[21] NG YP, CHEN Y, HU Y, IP FC, IP NY. Olean-12-eno[2,3-c] [1,2,5] oxadiazol-28-oic acid (OEOA) induces G1 cell cycle arrest and differentiation in human leukemia cell lines. PLoS One 2013; 8: e63580. https://doi.org/10.1371/journal. pone. 0063580 
[22] GAO L, XU Z, WANG Y, SUN B, ZONG Z et al. Anticancer effect of SZC017, a novel derivative of oleanolic acid, on human gastric cancer cells. Oncol Rep 2016; 35: 1101-1108.

[23] VICI P, PIZZUTI L, NATOLI C, GAMUCCI T, DI LAURO L et al. Triple positive breast cancer: a distinct subtype? Cancer Treat Rev 2015; 41: 69-76. https://doi.org/10.1016/j. ctrv.2014.12.005

[24] AHSAN A, HAN G, PAN J, LIU S, PADHIAR AA et al. Phosphocreatine protects endothelial cells from oxidized low-density lipoprotein-induced apoptosis by modulating the PI3K/Akt/eNOS pathway. Apoptosis 2015; 20: 1563-1576. https://doi.org/10.1007/s10495-015-1175-4

[25] WANG Y, LIU Y, LIU X, JIANG L, YANG G et al. Citreoviridin Induces Autophagy-Dependent Apoptosis through Lysosomal-Mitochondrial Axis in Human Liver HepG2 Cells. Toxins (Basel) 2015; 7: 3030-3044. https://doi.org/10.3390/ toxins7083030

[26] RAISOVA M, HOSSINI AM, EBERLE J, RIEBELING C, WIEDER $\mathrm{T}$ et al. The Bax/Bcl-2 ratio determines the susceptibility of human melanoma cells to CD95/ Fas-mediated apoptosis. J Invest Dermatol 2001; 117: 333-340. https://doi. org/10.1046/j.0022-202x.2001.01409.x

[27] CONWAY EM, POLLEFEYT S, STEINER-MOSONYI M, LUO W, DEVRIESE A et al. Deficiency of survivin in transgenic mice exacerbates Fas-induced apoptosis via mitochondrial pathways. Gastroenterology 2002; 123: 619-631. https://doi. org/10.1053/gast.2002.34753

[28] KONOPLEVA M, TSAO T, ESTROV Z, LEE RM, WANG RY et al. The synthetic triterpenoid2-cyano-3, 12-dioxooleana-1, 9-dien-28-oic acid induces caspase-dependent and -independent apoptosis in acute myelogenous leukemia. Cancer Res 2004; 64: 7927-7935. https://doi.org/10.1158/0008-5472. CAN-03-2402

[29] CHAKRAVARTI B, MAURYA R, SIDDIQUI JA, BID HK, RAJENDRN SM et al. In vitro anti-breast cancer activity of ethanolic extract of Wrightia tomentosa: role of pro-apoptotic effects of oleanolic acid and urosolic acid. J Ethnopharmacol 2012; 142: 72-79. https://doi.org/10.1016/j.jep.2012.04.015

[30] WANG X, BAI H, ZHANG X, LIU J, CAO P et al. Inhibitory effect of oleanolic acid on hepatocellular carcinoma via ERK-p53-mediated cell cycle arrest and mitochondrialdependent apoptosis. Carcinogenesis 2013; 34: 1323-1330. https://doi.org/10.1093/carcin/bgt058

[31] WEI J, LIU M, LIU H, WANG H, WANG F et al. Oleanolic acid arrests cell cycle and induces apoptosis via ROS mitochondrial depolarization and lysosomal membrane permeabilization in human pancreatic cancer cells. J Appl Toxicol 2013; 33: 756-765. https://doi.org/10.1002/jat.2725

[32] DEEB D, GAO X, LIU Y, VARMA NR, ARBAB AS et al. Inhibition of telomerase activity by oleanane triterpenoid CDDO-Me in pancreatic cancer cells is ROS-dependent. Molecules 2013; 18: 3250-3265. https://doi.org/10.3390/ molecules 18033250

[33] GAO X, DEEB D, LIU P, LIU Y, ARBAB-ALI S et al. Role of reactive oxygen species (ROS) in CDDO-Me-mediated growth inhibition and apoptosis in colorectal cancer cells. J Exp Ther Oncol 2011; 9: 119-127.
[34] HOLMSTROM KM, FINKEL T. Cellular mechanisms and physiological consequences of redox-dependent signalling. Nat Rev Mol Cell Biol 2014; 15: 411-421. https://doi. org/10.1038/nrm3801

[35] GERASIMENKO JV, GERASIMENKO OV, PALEJWALA A, TEPIKIN AV, PETERSEN OH et al. Menadione-induced apoptosis: roles of cytosolic elevations and the mitochondrial permeability transition pore. J Cell Sci 2002; 115: 485-498.

[36] TAO L, FU R, WANG X, YAO J, ZHOU Y et al. LL-202, a newly synthesized flavonoid, inhibits tumor growth via inducing G2/M phase arrest and cell apoptosis in MCF-7 human breast cancer cells in vitro and in vivo. Toxicol Lett 2014; 228: 1-12. https://doi.org/10.1016/j.toxlet.2014.04.002

[37] MA LL, WANG DW, YU XD, ZHOU YL. Tangeretin induces cell cycle arrest and apoptosis through upregulation of PTEN expression in glioma cells. Biomed Pharmacother 2016; 81: 491-496. https://doi.org/10.1016/j. biopha.2016.04.006

[38] DECRAENE D, AGOSTINIS P, BOUILLON R, DEGREEF H, GARMYN M. Insulin- like Growth Factor-1-mediated AKT Activation Postpones the Onset of Ultraviolet B-induced Apoptosis, Providing More Time for Cyclobutane Thymine Dimer Removal in Primary Human Keratinocytes. J Biol Chem 2002; 227: 32587-32595. https://doi.org/10.1074/jbc. M111106200

[39] OSAKI M, OSHIMURA M, ITO H. PI3K-Akt pathway: Its functions and alterations in human cancer. Apoptosis 2004; 9 : 667-676. https://doi.org/10.1023/B:APPT.0000045801.15585. dd

[40] NAKANISHI C, TOI M. Nuclear factor-kappaB inhibitors as sensitizers to anticancer drugs. Nat Rev Cancer 2005; 5: 297-369. https://doi.org/10.1038/nrc1588

[41] HAYDEN MS, GHOSH S. Shared principles in NF-kappaB signaling. Cell 2008; 132: 344-362. https://doi.org/10.1016/j. cell.2008.01.020

[42] XU D, MA Y, ZHAO B, LI S, ZHANG Y et al. Thymoquinone induces G2/M arrest, inactivates PI3K/Akt and nuclear factor- $\kappa \mathrm{B}$ pathways in human cholangiocarcinomas both in vitro and in vivo. Oncol Rep 2014; 31: 2063-2070. https://doi. org/10.3892/or.2014.3059

[43] AHMAD A, BIERSACK B, LI Y, KONG D, BAO B et al. Targeted Regulation of PI3K/Akt/mTOR/NF- $\kappa B$ signaling by Indole compounds and their derivatives: mechanistic details and biological implications for Cancer Therapy. Anticancer Agents Med Chem 2013; 13: 1002-1013. https://doi.org/10.21 74/18715206113139990078

[44] JEONG SJ, PISE-MASISON CA, RADONOVICH MF, PARK HU, BRADY JN. Activated AKT regulates NF-kappaB activation, p53 inhibition and cell survival in HTLV-1-transformed cells. Oncogene 2005; 24: 6719-6728. https://doi.org/10.1038/ sj.onc. 1208825

[45] YANG YI, LEE KT, PARK HJ, KIM TJ, CHOI YS et al. Tectorigenin sensitizes paclitaxel-resistant human ovarian cancer cells through downregulation of the Akt and NF kappa B pathway. Carcinogenesis 2012; 33: 2488-2498. https://doi. org/10.1093/carcin/bgs302 
[46] KIM J, SHIM M. COX-2 inhibitor NS-398 suppresses doxorubicin-induced p53 accumulation through inhibition of ROS-mediated Jnk activation. Mol Carcinog 2016;55 (12):2156-2167. https://doi.org/10.1002/mc.22458

[47] FU L, CHEN W, GUO W, WANG J, TIAN Y et al. Berberine Targets AP-2/h TERT, NF- $\kappa$ B/COX-2, HIF-1 $\alpha /$ VEGF and Cytochrome-c/ Caspase Signaling to Suppress Human
Cancer Cell Growth. PLoS One 2013; 8: e69240. https://doi. org/10.1371/journal.pone.0069240

[48] LIN C, CRAWFORD DR, LIN S, HWANG J, SEBUYIRA A et al. Inducible COX-2-dependent apoptosis in human ovarian cancer cells. Carcinogenesis 2011; 32: 19-26. https://doi. org/10.1093/carcin/bgq212 